\title{
Pengaruh Motivasi Kerja, Lingkungan Kerja, Budaya Kerja Terhadap Kinerja Karyawan Dinas Sosial Kabupaten Jember
}

\author{
Risky Nur Adha, Nurul Qomariah, Achmad Hasan Hafidzi \\ Fakultas Ekonomi Universitas Muhammadiyah Jember \\ Email: nurulqomariah@unmuhjember.ac.id dan achmad.hasan@unmuhjember..ac.id
}

\begin{abstract}
ABSTRAK
Penelitian ini bertujuan untuk mengetahui pengaruh motivasi kerja, lingkungan kerja dan budaya kerja terhadap kinerja karyawan. Motivasi kerja (X1), lingkungan kerja (X2), dan budaya kerja (X3) merupakan variabel independen dan kinerja karyawan sebagai variabel dependen (Y). Populasi dari penelitian ini adalah karyawan Dinas Sosial Kabupaten Jember yang berjumlah 32 orang. Alat analisis yang digunakan dalam penelitian ini yaitu uji validitas, uji reliabilitas, uji asumsi klasik, analisis regresi linier berganda, uji T, uji F dan uji R2. Hasil pengujian hipotesis pertama (H1) menunjukkan bahwa tidak ada pengaruh yang signifikan antara motivasi kerja terhadap kinerja karyawan dengan tingkat signifikasi sebesar 0.549 (p>0,05). Hipotesis kedua (H2) menunjukan bahwa ada pengaruh yang signifikan antara lingkungan kerja terhadap kinerja karyawan dengan tingkat signifikasi sebesar 0,009 $(\mathrm{p}<0,05)$. Hipotesis ketiga (H3) menunjukan bahwa ada pengaruh yang signifikan antara lingkungan kerja terhadap turnover intention dengan tingkat signifikasi sebesar 0,005 $(\mathrm{p}<0,05)$. Hasil penelitian menunjukan bahwa lingkungan kerja dan budaya kerja berpengaruh positif dan signifikan terhadap kinerja karyawan. Sedangkan motivasi kerjatidak berpengaruh terhadap kinerja karyawan.
\end{abstract}

Kata Kunci : motivasi kerja, lingkungan kerja, budaya kerja, dan kinerja karyawan.

\begin{abstract}
This study aims to determine the effect of work motivation, work environment and work culture on employee performance. Work motivation (X1), work environment (X2), and work culture (X3) are independent variables and employee performance as the dependent variable (Y). The population of this study were 32 Social Workers of Jember Regency. The analytical tool used in this study is the validity test, reliability test, classic assumption test, multiple linear regression analysis, $\mathrm{T}$ test, $\mathrm{F}$ test and $\mathrm{R} 2$ test. The results of testing the first hypothesis (H1) indicate that there is no significant effect between work motivation on employee performance with a significance level of 0.549 ( $p>0.05$ ). The second hypothesis (H2) shows that there is a significant influence between the work environment on employee performance with a significance level of $0.009(\mathrm{p}<0.05)$. The third hypothesis (H3) shows that there is a significant influence between the work environment and turnover intention with a significance level of $0.005(\mathrm{p}<0.05)$. The results showed that the work environment and work culture had a positive and significant effect on employee performance. While work motivation does not affect employee performance.
\end{abstract}

Keywords: work motivation, work environment, work culture, and employee performance 


\section{PENDAHULUAN}

Pesatnya perkembangan ilmu pengetahuan dan teknologi telah meningkatkan persaingan antar institusi. Pada abad ke 21, tantangan yang langsung dihadapi adalah globalisasi dengan segala implikasinya. Agar badan usaha tetap eksis maka harus berani menghadapinya, yaitu menghadapi perubahan dan memenangkan persaingan. Sumber daya yang dimiliki oleh institusi seperti modal, metode, dan mesin tidak bisa memberikan hasil yang optimal apabila tidak didukung oleh sumber daya manusia yang mempunyai kinerja optimal. Sehingga perusahaan membutuhkan karyawan yang mampu bekerja lebih baik dan lebih cepat, dan diperlukan karyawan yang mempunyai kinerja yang tinggi.

Seiring dengan perkembangan ilmu pengetahuan dan teknologi yang terus meningkat pesat, telah menciptakan suatu kondisi yang dinamis dan telah merubah paradigma baru dalam perkembangan dunia antar institusi. Dengan kondisi seperti ini ternyata telah menciptakan persaingan yang memerlukan perhatian serius dari setiap organisasi yang dituntut untuk mempunyai kemampuan yang strategis dan konkrit dalam mengambil langkah-langkah agar dapat beradaptasi terhadap perubahan iklim yang semakin dinamis. Berpijak dari kondisi tersebut maka sangatlah memerlukan suatu pemikiran untuk melihat bahwa kondisi sosial masyarakat, banyaknya ragam kelas-kelas sosial, agama dan latar belakang pendidikan menjadi konsentrasi yang harus diperhatikan secara serius, sehingga sumber daya manusia dalam suatu institusi atau perusahaan dapat berjalan selaras.

Sumber daya manusia (SDM) merupakan salah satu faktor yang sangat penting bahkan tidak bisa dilepaskan dari sebuah organisasi, baik perusahaan maupun institusi. Selain itu, SDM juga merupakan faktor yang mempengaruhi perkembangan suatu perusahaan. Jadi bisa dikatakan sebuah perusahaan dapat berkembang dengan sangat pesat apabila di dalamnya memiliki banyak SDM yang berkompeten di bidangnya, sebaliknya pula apabila SDM yang bekerja di sebuah perusahaan itu tidak berkualitas maka perkembangan perusahaan tersebut juga akan terhambat.

Satuan Kerja Perangkat Daerah (SKPD) adalah pelaksana fungsi eksekutif yang harus berkoordinasi agar penyelenggaraan pemerintahan berjalan dengan baik. Tujuan dari SKPD Dinas Sosial Kabupaten Jember adalah meningkatkan kualitas lingkungan sosial, dalam hal ini dapat diartikan terjaganya fungsi sosial dalam suatu institusi. Bicara mengenai fungsi sosial tidak akan terlepas dari kemampuan lingkungan untuk menopang kehidupan atau kerap dikenal sebagai daya dukung dan kemampuan lingkungan. Dengan adanya SKPD ini, diharapkan Dinas Sosial Kabupaten Jember mampu meningkatkan kinerja karyawan lewat pengembangan pengenalan lingkungan kota jember. Dalam hal ini pemerintah juga menekankan agar Dinas Sosial mampu meningkatkan perluasan pengenalan tentang wilayah khususnya Kabupaten Jember dengan cara gencar mempromosikan keanekaragaman budaya di wilayah jember. Meningkatkan taraf kesejahteraan sosial khususnya penyandang masalah kesejahteraan sosial, serta memperkuat kelembagaan dan potensi kesejahteraan sosial untuk mendorong inisiatif dan partisi aktif masyarakat. Hal ini dikarenakan semakin wilayah kabupaten jember 
dikenal oleh masyarakat luas, maka SKPD pada Dinas Sosial Kabupaten Jember dapat dikatakan berjalan dengan baik.

Persaingan yang semakin ketat mengharuskan perusahaan meningkatkan kinerja karyawan agar dapat bersaing dengan perusahaan lain. Kinerja karyawan adalah suatu proses penilaian kemajuan pekerjaan terhadap tujuan dan sasaran yang telah ditentukan sebelumnya, termasuk informasi atas efisiensi penggunaan sumber daya dalam menghasilkan barang dan jasa, kualitas barang dan jasa, hasil kegiatan dibandingkan dengan maksud yang diinginkan, dan efektivitas tindakan dalam mencapai tujuan. Pengukuran kinerja digunakan untuk menilai prestasi manajemen dan unit organisasi yang dipimpinnya. Pengukuran kinerja sangat penting untuk menilai akuntabilitas organisasi dan manajer dalam pelayanan publik yang lebih baik. Akuntabilitas disini bukan sekedar kemampuan menunjukkan uang publik dibelanjakan, akan tetapi juga meliputi kemampuan menunjukan bahwa uang publik tersebut telah dibelanjakan secara ekonomies, efisien, dan efektif. Sistem pengukuran kinerja adalah suatu sistem yang bertujuan untuk membantu manajer publik menilai pencapaian suatu strategi melalui alat ukur finansial dan non finansial. Sistem pengukuran kinerja dapat dijadikan alat pengendalian organisasi, karena pengukuran kinerja diperkuat dengan menetapkan reward and punishment systems.

Kinerja merupakan istilah yang berasal dari kata job perfornence atau actual performance (prestasi kerja atau prestasi sesungguhnya dicapai seseorang). Terdapat dua faktor yang mempengaruhi kinerja karyawan yaitu faktor dalam diri pegawai dan faktor pekerjaanya. Faktor yang ada pada diri pegawai yaitu kecerdasan (IQ), kecakapan khusus, umur, jenis kelamin, masa kerja, kepribadian, emosi, cara berfikir, persepsi dan sikap kerja. Kinerja adalah hasil kerja secara kualitas dan kuantitas yang dicapai seseorang pegawai dalam melaksanakan tugasnya sesuai dengan tanggung jawab yang diberiakan kepadanya (Mangkunegara, 2008).

Dinas Sosial Kabupaten Jember, ditetapkan berdasarkan peraturan Bupati nomor 48 tahun 2008 sebagai implementasi peraturan daerah nomer 15 tahun 2008, adalah unsur pelaksana pemerintah Kabupaten Jember yang mempunyai tugas menyelenggarakan kewenangan pemerintah dibidang sosial. dinas sosial dipimpin oleh kepala dinas yang berada dibawah dan bertanggung jawab kepada bupati melalui sekretaris kabupaten. Dinas sosial dalam melaksanakan tugasnya didalam teknis administratif dibina dan dikoordinasikan oleh sekretaris daerah.

Namun demikian dalam upaya menciptakan kinerja kerja karyawan pada Dinas Sosial Kabupaten Jember, Nampaknya masih terdapat banyak kendala yang dihadapi sehingga sulit untuk mencapai tujuan organisasi. Kondisi yang belum ideal masih ada di Dinas Sosial Kabupaten Jember. Dimana masih ada kendala lain diantaranya, karyawan yang tidak bisa berkomunikasi dengan baik antar individu maupun kelompok, karyawan yang datang kerja terlambat, dan tidak masuk kerja tanpa ijin. Sehingga mengakibatkan kinerja karyawan menurun yang disebabkan karyawan yang selalu membuat kesalahan dan motivasi karyawan yang rendah dalam mengerjakan pekerjaan, sehingga pekerjaan karyawan tidak dapat terselesaikan seuai dengan yang direncanakan.

Untuk meningkatkan kinerja karyawan diperlukan motivasi kerja, lingkungan kerja dan budaya kerja yang dapat mendorong karyawan meningkatkan kinerja karyawan. Faktor yang mempengaruhi motivasi kerja karyawan menurut Herzberg 
(2008) terdiri atas dua faktor yaitu, motifation factor dan hygieni factor. Motifation factor adalah daya dorong yang timbul dari dalam diri masing-masing pegawai. Sedangkan hygieni factor merupakan daya dorong yang datang dari luar diri pegawai terutama dari organisasi atau lembaga tempat bekerja. Daya dorong dari luar diri pegawai biasanya berupa kompensasi kompensasi yang diterima dan lingkungan kerja sebagai penunjang saat pekerja.

Antoni (2008) mengemukakan bahwa pemberian dorongan sebagai salah satu bentuk motivasi, penting dilakukan untuk meningkatkan gairah kerja karyawan sehingga dapat mencapai hasil yang dikehendaki oleh manajemen. Hubungan motivasi, gairah kerja dan hasil optimal mempunyai bentuk linear dalam arti dengan pemberian motivasi kerja yang baik, maka gairah kerja karyawan akan meningkat dan hasil kerja akan optimal sesuai dengan standart kinerja yang ditetapkan. Menurut McDonald dalam Oemar Hamalik (1992:173) motivasi merupakan suatu perubahan energy di dalam pribadi seseorang yang ditandai dengan timbulnya afeksi dan reaksi untuk mencapai tujuan. Hal ini sudah sesuai dengan penelitian yang dilakukan oleh Sulton (2017) menyatakan bahwa motivasi kerja berpengaruh signifikan terhadap kinerja karyawan.

Sedarmayanti (2011), mendifinisikan lingkungan kerja sebagai keseluruhan alat perkakas dan bahan yang dihadapi, lingkungan sekitarnya dimana seseorang bekerja, metode kerjanya, serta pengatur kerjanya baik sebagai perseorangan maupun sebagai kelompok. Lingkungan kerja merupakan salah satu faktor penting dalam menciptakan kinerja karyawan. Faktor yang mempengaruhi lingkungan kerja antara lain seperti penerangan ditempat kerja, suhu udara, keamanan kerja, dan hubungan dengan karyawan. Nitisemito (2008) mengatakan bahwa lingkungan kerja juga merupakan segala sesuatu yang ada disekitar para pekerja yang dapat mempengaruhi dirinya dalam menjalankan tugas-tugas yang dibebankan dan merupakan salah satu faktor yang mempengaruhi kinerja seorang pegawai. Lingkungan kerja mempunyai pengaruh langsung terhadap karyawan didalam menyelesaikan pekerjaan. Hal ini sudah sesuai dengan penelitian yang dilakukan Maulidia (2017) menyatakan bahwa lingkungan kerja berpengaruh signifikan terhadap kinerja karyawan.

Nawawi (2005) budaya kerja adalah kebiasaan yang dilakukan berulang-ulang oleh pegawai dalam suatu organisasi. Budaya kerja mempunyai arti yang sangat dalam, karena akan merubah sikap dan prilaku sumber daya manusia untuk mencapai produktivitas kerja yang lebih tinggi dalam menghadapi tantangan masa depan. Schein (2010) mendefinisikan budaya sebagai suatu pola asumsi dasar bersama yang dipelajari kelompok tertentu untuk mengatasi masalah adaptasi eksternal dan integrasi internal. Budaya merupakan suatu keseluruhan dari pola prilaku yang terlihat dalam kehidupan sosial, seni, agama, kelembagaan, dan semua hasil kerja dan pemikiran dari suatu kelompok manusia. Lima faktor yang mempengaruhi budaya kerja yaitu tanggung jawab karyawan, inovasi, orientasi pada hasil, pengetahuan dan sistem kerja. Faktor-faktor tersebut secara langsung akan mempengaruhi budaya kerja karyawan dalam suatu perusahaan atau organisasi. Hal ini sudah sesuai dengan penelitian yang dilakukan Shodiyah (2017) menyatakan budaya kerja berpengaruh signifikan terhadap kinerja karyawan.

Sutrisno (2010) mengatakan bahwa kinerja merupakan hasil kerja baik kualitas maupun kuantitas yang dihasilkan karyawan atau prilaku nyata yang dihasilkan sesuai 
dengan tanggung jawab yang diberikan kepadanya. Kinerja merupakan performa yang berarti hasil kerja seorang pekerja, sebuah proses manajemen atau suatu organisasi secara keseluruhan, dimana hasil kerja tersebut harus dapat ditunjukkan buktinya secara konkrit dan dapat diukur. Pengertian Kinerja merupakan suatu hasil kerja yang dihasilkan oleh seorang pegawai diartikan untuk mencapai tujuan yang diharapkan. Hal ini sudah sesuai dengan penelitian yang dilakukan oleh Handawiyah (2015) menyatakan bahwa kinerja karyawan berpengaruh signifikan terhadap peningkatan mutu perusahaan.

Berdasarkan observasi yang telah dilakukan di Dinas Sosial Kabupaten Jember terdapat indikasi masih rendahnya motivasi kerja para karyawan yang ada di instansi tersebut. Dalam kaitanya dengan kinerja karyawan motivasi yang rendah dapat berpengaruh terhadap kinerja karyawan yang tidak maksimal (Siagian, 2013). Dari informasi pihak dinas menunjukkan bahwa tingkat kehadiran karyawan belum memenuhi tuntutan organisasi. Hal ini menjadi tantangan bagi Dinas Sosial Kabupaten Jember untuk mempertahankan tingkat kehadiran karyawan, disamping itu terus berupaya agar tingkat kehadiran karyawan tersebut semakin meningkat. Kestabilan tersebut akan menjadi bukti bahwa Dinas Sosial Kabupaten Jember telah melakukan usaha yang kuat untuk meningkatkan kinerja karyawan agar menjadi lebih baik.

Berdasarkan latar belakang yang telah diungkapkan dapat dibuat rumusan masalah sebagai berikut :

1. Apakah motivasi kerja berpengaruh terhadap kinerja karyawan pada Dinas Sosial Kabupaten Jember?

2. Apakah lingkungan kerja berpengaruh terhadap kinerja karyawan pada Dinas Sosial Kabupaten Jember?

3. Apakah budaya kerja berpengaruh terhadap kinerja karyawan pada Dinas Sosial Kabupaten Jember?

4. Apakah motivasi kerja, lingkungan kerja, dan budaya kerja berpengaruh terhadap kinerja karyawan pada Dinas Sosial Kabupaten Jember?

Dari rumusan masalah yang sudah dirancang maka tujuan penelitian ini adalah untuk menganalisis dan mengetahui pengaruh motivasi kerja, lingkungan kerja dan budaya kerja terhadap kinerja karyawan pada Dinas Sosial Kabupaten Jember.

\section{Manajemen Sumber Daya Manusia}

\section{TINJAUAN PUSTAKA}

Sofyandi (2009) menyatakan bahwa manajemen sumber daya manusia adalah suatu strategi dalam menerapkan fungsi-fungsi manajemen yaitu planning, organizing, leading and controlling, dalam setiap aktifitas atau fungsi operasional sumber daya manusia mulai dari proses penarikan, seleksi, pelatihan dan pengembangan, penempatan yang meliputi promosi, demosi dan transfer, penilaian kinerja, pemberian kompensasi, hubungan industrial, hingga pemutusan hubungan kerja, yang ditujukan bagi peningkatan kontribusi produktif dari sumberdaya manusia organisasi terhadap pencapaian tujuan organisasi secara lebih efektif dan efisien.

\section{Kinerja Karyawan}

Kinerja karyawan sangat dipengaruhi dan bahkan tergantung pada kualitas dan kemampuan kompetitif sumber daya manusia yang dimilikinya. Kinerja seorang pegawai merupakan hal yang bersifat individual, karena setiap pegawai mempunyai tingkat kemampuan yang berbeda-beda dalam mengerjakan tugasnya. Pihak manajemen dapat mengukur pegawai atas unjuk kerjanya berdasarkan kinerja masing-masing pegawai. 
Robbins(2008) menyatakan bahwa kinerja karyawan adalah banyaknya upaya yang dikeluarkan individu dalam mencurahkan tenaga sejumlah tertentu kepada pekerjaan. Mangkunegara (2010) kinerja karyawan adalah hasil kerja secara kualitas dan kuantitas yang dicapai oleh seorang karyawan dalam melaksanakan tugasnya sesuai dengan tanggung jawab yang diberikan kepadanya. Sutrisno (2010) kinerja karyawan adalah prestasi yang diperoleh seseorang dalam melakukan tugas. Azhad, dkk. (2015) menyatakan bahwa kinerja merupakan hasil yang dicapai oleh karyawan dalam periode tertentu.

\section{Motivasi Kerja}

Hasibuan (2008)menyatakan bahwa motivasi adalah pemberian daya penggerak yang menciptakan kegairahan kerja seseorang agar mereka mampu bekerjasama, bekerja efektif, dan terintegritas dengan segala daya upayanya untuk mencapai kepuasan. Motivasi adalah suatu yang pokok yang menjadikan dorongan bagi seseorang untuk bekerja. Dessler (2009) mengemukakan secara teoritis motivasi terbentuk karena manusia memiliki kategori kebutuhan pokok seperti kebutuhan fisiologi, rasa aman, sosial, ego,dan perwujudan diri. Kebutuhan tersebut membentuk suatu hirarki dan masing-masing akan aktif jika kebutuhan yang lebih rendah telah terpenuhi. Kebutuhan fisiologi merupakan kebutuhan pokok misalnya kebutuhan makanan, minuman, tempat tinggal dan sejenisnya. Kebutuhan rasa aman adalah kebutuhan yang muncul setelah kebutuhan pokok terpenuhi, misalnya kebutuhan jaminan keamanan. Kebutuhan sosial antara lain memberi dan menerima kasih sayang dan persahabatan. Kebutuhan ego mencakup kebutuhan yang berkaitan dengan kehormatan diri dan reputasi seseorang.

Robbins (2008) mendifinisikan motivasi sebagai proses yang menjelaskan intensitas, arah, dan ketekunan seorang individu untuk mencapai tujuannya. Tiga elemen utama dalam definisi tersebut adalah intensitas, arah, dan ketekunan. Intensitas berhubungan dengan seberapa giat seseorang berusaha. Ini adalah elemen yang paling banyak mendapat perhatian ketika membicarakan tentang motivasi. Namun intensitas yang tinggi sepertinya tidak akan menghasilkan prestasi kerja yang memuaskan kecuali upaya tersebut dikaitkan dengan arah yang menguntungkan organisasi. Dengan demikian kita harus mempertimbangkan kualitas serta intensitas upaya secara bersamaan. Upaya yang diarahkan dan konsisten dengan tujuan-tujuan organisasi merupakan jenis upaya yang seharusnya kita lakukan. Terakhir, motivasi memiliki dimensi ketekunan. Dimensi ini merupakan ukuran mengenai seberapa lama seseorang bisa mempertahankan usahanya. Individu-individu yang terinovasi bertahan melakukan suatu tugas dalam waktu yang cukup lama demi mencapai tujuan mereka (Robbins, 2008).

\section{Lingkungan Kerja}

Nitisemito (2008) menyatakan bahwa lingkungan kerja merupakan segala sesuatu yang ada disekitar para pekerja yang dapat mempengaruhi dirinya dalam menjalankan tugas-tugas yang dibebankan. Misalnya kebersihan, musik dan lain-lain. Sedarmayanti (2011) mendifinisikan lingkungan kerja sebagai keseluruhan alat perkakas dan bahan yang dihadapi, lingkungan sekitarnya dimana seseorang bekerja, metode kerjanya, serta pengatur kerjanya baik sebagai perseorangan maupun sebagai kelompok.

Lingkungan kerja merupakan salah satu faktor yang mempengaruhi kinerja seorang pegawai. Seorang pegawai yang bekerja dilingkungan kerja yang mendukung dia untuk bekerja secara optimal akan menghasilkan kinerja yang baik, sebaliknya jika 
seorang pegawai bekerja dalam lingkungan kerja yang tidak memadai dan tidak mendukung untuk bekerja secara optimal akan membuat pegawai yang bersangkutan menjadi malas, cepat lelah sehingga kinerja pegawai tersebut akan rendah (Bambang, 2011). Pegawai akan mampu mencapai kinerja jika maksimal jika memiliki motif berprestasi tinggi. Motif berprestasi yang perlu dimiliki oleh pegawai harus ditumbuhkan dari dalam diri sendiri dan dari lingkungan kerja. Hal ini karena motif berprestasi yang ditumbuhkan dalam diri sendiri akan membentuk suatu kekuatan diri dan jika situasi lingkungan kerja turut menunjang makan pencapaian kinerja akan lebih mudah (Mangkunegara, 2009). Dari beberapa pendapat diatas disimpulkan bahwa lingkungan kerja merupakan segala sesuatu yang ada disekitar pegawai pada saat bekerja, baik berbentuk fisik atau non fisik, langsung atau tidak langsung, yang dapat mempengaruhi dirinya dan pekerjanya saat bekerja.

\section{Budaya Kerja}

Nawawi (2005) menyatakan bahwa budaya kerja adalah kebiasaan yang dilakukan berulang-ulang oleh pegawai dalam suatu organisasi. Pelanggaran terhadap kebiasaan ini memang tidak ada sangsi tegas, namun dari prilaku organisasi secara moral telah menyepakati bahwa kebiasaan tersebut merupakan kebiasaan yang harus ditaati dalam rangka pelaksanaan pekerjaan untuk mencapai tujuan. Berdasarkan teori diatas budaya kerja, bahwasannya merupakan kebiasaan atau prilaku yang dilakuakan secara berulang-ulang pada setiap rutinitas dan tidak ada sangsi tegas jika melanggarnya, namun kebiasaan disini yang dimaksudkan kebiasaan yang bersifat positif. Kebiasaan itu merupakan gabungan dari sikap dan perilaku yang mana memiliki dimensi untuk dijadikan sebagai patokan dalam bersikap dan berprilaku.

\section{Populasi dan Sampel Penelitian}

\section{METODE PENELITIAN}

Sugiono (2009) menyatakan bahwa populasi adalah wilayah generalisasi yang terdiri atas obyek dan subyek yang mempunyai kualitas dan karakteristik tertentu yang diterapkan oleh peneliti untuk dipelajari dan kemudian ditarik kesimpulannya. Populasi yang dimaksud dalam penelitian ini adalah keseluruhan karyawan pada Dinas sosial Kabupaten Jember yang berjumlah 32 orang. Jumlah karyawan pada Dinas Sosial Kabupaten Jember sebanyak 32 orang maka penelitian ini menggunakan metode penelitian populasi (sensus).

\section{Definisi oprasional variabel}

A. Indikator motivasi kerja menurut Hasibuan (2008) yaitu:

1) Kebutuhan Fisik.

Kebutuhan akan fasilitas penunjang yang di dapat di tempat kerja, misalnya fasilitas penunjang untuk mempermudah penyelesaian tugas dikantor.

2) Kebutuhan rasa aman.

Kebutuhan-kebutuhan akan rasa aman ini, diataranya adalah rasa aman fisik, stailitas, ketergantungan, perlindungan dan kebebasan dari daya-daya mengancam seperti : takut, cemas, bahaya.

3) Kebutuhan sosial.

Kebutuhan yang harus dipenuhi berdasarkan kepentingan bersama dalam masyarakat, kebutuhan tersebut dipenui bersama-sama, contohnya interaksi yang baik antar sesama. 
4) Kebutuhan akan penghargaan.

Kebutuhan akan penghargaan atas apa yang telah dicapai oleh seseorang, contohnya kebutuhan akan status, kemuliaan, perhatian, reputasi.

5) Kebutuhan dorongan mencapai tujuan

Kebutuhan akan dorongan untuk mencapai sesuatu yang diinginkan, misalnya motivasi dari pimpinan.

B). Lingkungan Kerja (X2) :

Lingkungan kerja merupakan suatu yang ada disekitar para pekerja yang mempengaruhi dirinya dalam menjalankan tugas-tugas yang dibebankan indikatorindikator lingkungan kerja (Sedarmayati, 2011) adalah sebagai berikut :

1. Penerangan.

Intensitas cahaya yang dapat membantu pegawai dalam memperlancar aktivitas kerjanya.

2. Keamanan kerja.

Persentase keamanan ditempat kerja dapat membuat karyawan nyaman dalam bekerja.

3. Kondisi Kerja.

Pengaturan ruang kerja agar memudahkan karyawan berinteraksi sosial dengan karyawan lain.

4. Hubungan antara karyawan dan pimpinan.

Interaksi yang baik antara karyawan dan pimpinan mampu membuat atmosfer yang baik ditempet kerja.

5. Penggunaan warna.

Penggunaan warna yang sesuai akan membuat suasana kerja menjadi menyenagkan dan membuat karyawan menjadi betah di kantor.

\section{C). Budaya $\operatorname{Kerja}(\mathrm{X} 3)$ :}

Budaya kerja merupakan nilai-nilai sosial atau suatu keseluruhan pola prilaku diperusahaan yang berkaitan dengan akal dan budi karyawan dalam melakukan suatu pekerjaan. Berdasarkan Nawawi(2008) indikator budaya kerja dari penelitian ini menggunakan :

1. Melaksanakan pekerjaan sesuai tugas.

Karyawan mampu melaksanakan tugas yang diberikan dengan baik dan benar.

2. Jujur dalam bekerja.

Sifat jujur mampu membuat seseorang mendapatkan nilai lebih dimata orang lain. Jujur dalam bekerja juga mampu membuat karyawan mendapat kepercayaan lebih.

3. Komitmen kerja.

Memiliki komitmen yang tinggi mampu membuat seseorang termotivasi untuk menyelesaikan sesuatu sesuai dengan terget yang ditentukan.

4. Tanggung jawab terhadap pekerjaan.

Tanggung jawab mampu membuat seseorang mendapat kepercayaan lebih dari orang sekitar.

5. Mampu berjasama dengan rekan kerja.

Berinteraksi dan bekerja sama dengan baik dengan sesama masyarakat dapat membuat seseorang diterima di lingkungan tersebut dengan baik. 
D. Kinerja karyawan (Y).

Kinerja karyawan adalah fungsi pekerjaan atau kegiatan seseorang atau kelompok dalam suatu organisasi yang dipengaruhi oleh berbagai faktor untuk mencapai tujuan organisasi dalam periode waktu tertrentu (Tika, 2008) menyatakan pengukuran kinerja karyawan berdasarkan pada : kuantitas kerja, kualitas kerja, dan ketepatan waktu. Dengan menggunakan skala interval.

Kinerja karyawan merupan hasil kerja secara kualitas dan kuantitas yang dicapai oleh seseorang karyawan dalam melaksanakan tugasnya sesuai dengan tanggung jawab yang diberikan padanya. Sutrisno (2010), Indikatornya adalah :

1. Tingkat kerapian pekerjaan

Tingkat kerapian pekerjaan mampu memberi pengaruh yang baik bagi seseorang dalam menyelesaikan pekerjaan.

2. Ketetapan waktu dalam meneyelesaikan pekerjaan.

Tepat waktu dalam menyelesaikan suatu pekerjaan mempu memberikan nilai lebih kepada seseorang yang mengerjakannya.

3. Kualitas pekerjaan.

Kualias pekerjaan yang baik diharapkan dapat membuat karyawan mampu bertanggung jawab dengan apa yang mereka kerjakan.

4. Kuantitas pekerjaan.

Selalu mampu m,enyelesaikan pekerjaan sesuai target yang telah ditetapkan.

5. Pengetahuan kerja.

Mampu menganalisa dan megetahui pekerjaan yang diberikan dengan baik.

\section{Uji Validitas}

Uji validitas digunakan untuk mengukur sah atau tidaknya suatu kuesioner. Suatu kuesioner dikatakan valid jika pertanyaan pada kuesioner mampu untuk mengungkapkan sesuatu yang akan diukur oleh kuesioner tersebut (Ghozali, 2009). Dalam hal ini digunakan beberapa pertanyaan yang dapat secara tepat menggunakan variabel yang diukur tersebut. Untuk mengukur tingkat dapat dilakukan dengan cara mengkorelasikan antara skor butir pertanyaan dengan total skor konstruk atau variabel.

\section{Uji Reliabilitas}

Reabilitas sebenarnya adalah alat untuk mengukur suatu kuisioner yang merupakan indikator dari variabel atau konstruk. Suatu kuesioner dikatakan reliable atau handal jika jawaban seseorang terhadap pernyataan adalah konsisten atau stabil dari waktu ke waktu (Ghozali, 2009). Pengukuran reliabilitas dilakukan dengan cara one shot atau pengukuran sekali saja dengan alat bantu SPSS uji statistik Cronbach Alpha $(\alpha)$. Suatu konstruk atau variabel dikatakan reliable jika memberikan nilai Cronbach Alpha> 0.60 (Ghozali, 2009).

\section{Analisis Regresi Liner Berganda}

Analisis ini digunakan untuk menghitung seberapa besar pengaruh variabel bebas yaitu: Motivasi Kerja (X1), Lingkungan Kerja (X2), dan Budaya Kerja (X3) terhadap variabel terikat yaitu Kinerja Karyawan (Y).

Persamaan regresi linier berganda adalah sebagai berikut (Ghozali, 2009) :

$$
\mathrm{Y}=\mathrm{a}+\mathrm{b} 1 \mathrm{X} 1+\mathrm{b} 2 \mathrm{X} 2+\mathrm{b} 3 \mathrm{X} 3+\mathrm{e}
$$




\section{Analisis Koefisien Determinasi}

Koefisien determinan $\left(\mathrm{R}^{2}\right)$ dimaksudkan untuk mengetahui tingkat ketepatan paling baik dalam analisis regresi dan besarnya koefisiensi determinasi $\left(\mathrm{R}^{2}\right)$ antara 0 (nol) dan 1 (satu). Koefisien determinasi $\left(\mathrm{R}^{2}\right)$ nol variabel independen sama sekali tidak berpengaruh terhadap variabel dependen. Apabila koefisien determinasi semakin mendekati satu, maka dapat dikatakan bahwa variabel independent berpengaruh terhadap variabel dependen. Selain itu koefisien determinasi dipergunakan untuk mengetahui presentase perubahan variabel terikat (Y) yang disebabkan oleh variabel bebas (X) (Ghozali, 2009).

\section{Statistik Deskriptif Responden}

\section{HASIL DAN PEMBAHASAN}

Hasil perhitungan statisitik menunjukkan bahwa sebagian besar responden adalah laki-laki yakni sebanyak $17(53,1 \%)$ orang dan perempuan berjumlah $15(46,8 \%)$ orang. Berdasarkan usia responden terlihat bahwa dari 32 responden, sebagian besar responden berada dalam rentang usia 20-35 tahun yakni sebanyak 4 orang (12,5\%), sedangkan yang berada dalam rentang usia 35-45 tahun sebanyak 6 orang $(18,7 \%)$, dan responden berada dalam rentang usia $>45$ tahun sebanyak 22 responden $(68,7 \%)$. Berdasarkan pendidikan responden maka diperoleh data bahwa dari 32 responden, sebagian besar responden yang memiliki tingkat pendidikan terakhir memiliki pendidikan terakhir SLTA/Sederajat yakni sebanyak 4 orang (12,5\%), yang memiliki pendidikan terakhir Diploma yakni sebanyak 5 orang $(15,6 \%)$, yang memiliki pendidikan terakhir S1 yakni sebanyak 19 orang $(59,4 \%)$, dan yang memiliki pendidikan terakhir S2 yakni sebanyak 4 orang $(12,5 \%)$.

\section{Hasil Uji Validitas dan Reliabilitas}

Tabel 1. Hasil Pengujian Validitas

\begin{tabular}{|c|c|c|c|c|}
\hline \multicolumn{5}{|c|}{ Variabel/indikator } \\
\hline No & Motivasi Kerja & r hitung & r tabel & Keterangan \\
\hline 1 & $\mathrm{X} 1.1$ & 0,756 & 0.3494 & Valid \\
\hline 2 & $\mathrm{X} 1.2$ & 0,792 & 0.3494 & Valid \\
\hline 3 & $\mathrm{X} 1.3$ & 0,667 & 0.3494 & Valid \\
\hline 4 & $\mathrm{X} 1.4$ & 0,516 & 0.3494 & Valid \\
\hline \multirow[t]{2}{*}{5} & $X 1.5$ & 0,724 & 0.3494 & Valid \\
\hline & Lingkungan Ker & & & \\
\hline 1 & $\mathrm{X} 2.1$ & 0,661 & 0.3494 & Valid \\
\hline 2 & $\mathrm{X} 2.2$ & 0,669 & 0.3494 & Valid \\
\hline 3 & $\mathrm{X} 2.3$ & 0,807 & 0.3494 & Valid \\
\hline 4 & $\mathrm{X} 2.4$ & 0,708 & 0.3494 & Valid \\
\hline \multirow[t]{2}{*}{5} & $X 2.5$ & 0,813 & 0.3494 & Valid \\
\hline & Budaya Kerja & & & \\
\hline 1 & X3.1 & 0,564 & 0.3494 & Valid \\
\hline 2 & X3.2 & 0,767 & 0.3494 & Valid \\
\hline 3 & X3.3 & 0,838 & 0.3494 & Valid \\
\hline 4 & X3.4 & 0,669 & 0.3494 & Valid \\
\hline \multirow[t]{2}{*}{5} & X3.5 & 0,866 & 0.3494 & Valid \\
\hline & Kinerja Karyaw & & & \\
\hline 1 & $\mathrm{Y} 1$ & 0,578 & 0.3494 & Valid \\
\hline 2 & Y2 & 0,769 & 0.3494 & Valid \\
\hline 3 & Y3 & 0,757 & 0.3494 & Valid \\
\hline 4 & Y4 & 0,751 & 0.3494 & Valid \\
\hline 5 & Y5 & 0,728 & 0.3494 & Valid \\
\hline
\end{tabular}

Sumber: Data Diolah. 
Tabel 1 menunjukkan bahwa korelasi antara masing-masing indikator terhadap total skor konstruk dari setiap variabel menunjukkan hasil yang valid. Karena $r$ hitung $>r$ tabel. Sehinhgga dapat disimpulkan bahwa semua item pernyataan dinyatakan valid.

Tabel 2. Hasil Pengujian Reliabilitas

\begin{tabular}{clccl}
\hline No & \multicolumn{1}{c}{ Variabel } & $\begin{array}{c}\text { Alpha } \\
\text { Hitung }\end{array}$ & Standar Alpha & Keterangan \\
\hline 1 & Motivasi Kerja (X1) & 0,704 & 0,600 & Reliabel \\
2 & Lingkungan Kerja (X2) & 0,765 & 0,600 & Reliabel \\
3 & Budaya Kerja (X3) & 0,746 & 0,600 & Reliabel \\
4 & Kinerja Karyawan (Y) & 0,755 & 0,600 & Reliabel \\
\hline
\end{tabular}

Sumber: Data Diolah.

Hasil uji reliabilitas untuk semua variabel dinyatakan reliable dikarenakan semua variabel mempunyai nilai alfa cronbach diatas 0.60 .

\section{Analisis Regresi Linier Berganda}

Analisis ini digunakan untuk menghitung seberapa besar pengaruh variabel bebas yaitu : motivasi kerja (X1), Lingkungan Kerja (X2), dan Budaya Kerja (X3) terhadap variabel terikat yaitu kinerja karyawan (Y). Persamaan regresi linier berganda adalah sebagai berikut (Ghozali, 2009).

Tabel 3. Hasil Analisis Regresi Linier Berganda

\begin{tabular}{clcc}
\hline No & \multicolumn{1}{c}{ Variabel } & Koefisien Regresi & Standart Eror \\
1 & Kinerja Karyawan (Y) & 5,406 & 3,109 \\
2 & Motivasi Kerja (X1) & $-0,083$ & 0,136 \\
3 & Lingkungan Kerja (X2) & 0,379 & 0,134 \\
4 & Budaya Kerja (X3) & 0,458 & 0,151 \\
\hline
\end{tabular}

Sumber Data Diolah.

Hasil persamaan regresi berganda tersebut, dijelaskan sebagai berikut :

1. $b_{1}$ (nilai koefisien regresi motivasi kerja) bernilai negatif, mempunyai arti apabila motivasi kerja meningkat maka kinerja karyawan akan menurun. hal ini disebabkan karena motivasi kerja tidak sesuai dengan apa yang diharapkan oleh karyawan.

2. $b_{2}$ (nilai koefisien regresi lingkungan kerja) berniali positif, mempunyai arti apabila lingkungan kerja pada Dinas Sosial Kabupaten Jember meningkat maka kinerja karyawan semakin meningkat.

3. b3 $_{3}$ (nilai koefisien regresi budaya kerja) bernilai positif, mempunyai arti apabila budaya kerja pada Dinas Sosial Kabupaten Jember meningkat maka kinerja karyawan semakin meningkat.

\section{Koefisien Detereminasi $\left(\mathbf{R}^{2}\right)$}

Koefisien determinasi merupakan besaran yang menunjukan besarnya variasi variabel dependen yang dapat dijelaskan oleh variabel independennya. Dengan kata lain, koefisien determinasi ini digunakan untuk mengukur seberapa jauh variabel-variabel bebas dalam menerangkan variabel terikatnya. Hasil perhitungan menunjukkan besarnya adjusted $\mathrm{R}^{2}$ adalah 0,499 hal ini berarti 49,9\% variabel kinerja karyawan dapat dijelaskan oleh ke tiga variabel independen motivasi kerja, lingkungan kerja, dan budaya kerja. 
Sedangkan sisanya $(100 \%-49,9 \%=50,1 \%)$ dijelaskan oleh sebab-sebab lain diluar model penelitian.

\section{Pengujian Hipotesis}

Uji t digunakan untuk menguji signifikan hubungan antara $\mathrm{X}$ dan $\mathrm{Y}$ apakah variabel X1, X2, X3, (motivasi kerja, lingkungan kerja, dan budaya kerja) benar-benar berpengaruh terhadap variabel Y (Kinerja Karyawan) secara terpisah atau parsial. (Ghozali, 2009). Sedangkan untuk menentukan tabel distribusi t dicari pada $\alpha=5 \%$ dengan derajat kebebasan (df) n-k-1 atau 32-4-1=27.

Tabel 4. Hasil Uji t

\begin{tabular}{ccccc}
\hline Model & Nilai Sig & T hitung & T tabel & Ket \\
\hline X1 & 0,549 & $-0,607$ & 1,703 & Tidak sig \\
X2 & 0,009 & 2,828 & 1,703 & Sig \\
X3 & 0,005 & 3,026 & 1,703 & Sig \\
\hline
\end{tabular}

Sumber : Data Diolah.

Berdasarkan nilai statistik hasil analisis pada tabel 4. dapat dilihat dibawah ini :

1. Hasil dari perhitungan yaitu Motivasi Kerja $(X 1)=$ nilai sig $0,549>0.05$, dan $T$ hitung $-0,607<\mathrm{T}$ tabel 1.703 , sehingga dapat disimpulkan bahwa variabel motivasi kerja (X1) tidak berpengaruh signifikan terhadap variabel Kinerja Karyawan (Y).

2. Hasil dari perhitungan yaitu Lingkungan Kerja $(X 2)=$ nilai sig. $0.009<0.05$, dan $T$ hitung 2,828 > $\mathrm{T}$ tabel 1.703, sehingga dapat disimpulkan bahwa variabel Lingkungan Kerja (X2) berpengaruh signifikan terhadap variabel Kinerja Karyawan (Y).

3. Hasil dari perhitungan yaitu Budaya Kerja $(X 5)=$ nilai sig. $0.005<0.05$, dan $T$ hitung 3,026 > Ttabel 1.703, sehingga dapat disimpulkan bahwa variabel Budaya Kerja (X3) berpengaruh signifikan terhadap variabel Kinerja Karyawan (Y).

\section{Pembahasan}

Berdasarkan penelitian yang telah dilakukan dan melibatkan 32 responden pada Dinas Sosial Kabupaten Jember dengan instrumen penelitian untuk mengukur variabel motivasi kerja, lingkungan kerja, dan budaya kerja terhadap kinerja karyawan, dari uji validitas dan reabilitas diketahui seluruh item dari masing-masing adalah valid dan reliabel karena $r$ hitung masing-masing dari semua variabel $>\mathrm{r}$ tabel.

\section{Pengaruh Motivasi Kerja terhadap Kinerja Karyawan.}

Dari perhitungan statistik dapat disimpulkan nilai signifikansi sebesar $0.549>$ 0.05 dan $\mathrm{t}$ hitung $-0.607<\mathrm{t}$ tabel 1,703 . Hal ini berarti hipotesis yang menyatakan motivasi kerja tidak berpengaruh secara signifikan terhadap kinerja karyawan Dinas Sosial Kabupaten Jember ditolak. Motivasi merupakan suatu perubahan energy di dalam pribadi seseorang yang ditandai dengan timbulnya afeksi dan reaksi untuk mencapai tujuan tertentu McDonald dalam Oemar Hamalik (1992:173). Hasil ini tidak mendukung penelitian sebelumnya yang dilakukan oleh Sulton (2017) yang menyatakan motivasi kerja, kepemimpinan dan budaya organisasi berpengaruh positif dan signifikan terhadap kepuasan kerja karyawan pada Dinas Sosial Kabupaten Jember. 


\section{Pengaruh Lingkungan Kerja terhadap Kinerja Karyawan.}

Dari perhitungan statistik menunjukan nilai signifikansi sebesar $0.009<0.05$ dan t hitung 2,828 < t tabel 1,703. Hal ini berarti hipotesis yang menyatakan lingkungan kerja berpengaruh secara signifikan terhadap kinerja karyawan Dinas Sosial Kabupaten Jember diterima. Lingkungan kerja merupakan segala sesuatu yang ada disekitar para pekerja yang dapat mempengaruhi dirinya dalam menjalankan tugas-tugas yang dibebankan, serta merupakan salah satu faktor yang mempengaruhi kinerja seorang pegawai Nitisemito (2008). Hasil ini mendukung penelitian sebelumnya yang dilakukan oleh Priyono, dkk. (2018) yang menyatakan lingkungan kerja berpengaruh positif terhadap kinerja karyawan.

\section{Pengaruh Budaya Kerja terhadap Kinerja Karyawan.}

Dari perhitungan statistik menunjukan nilai signifikansi sebesar $0.005<0.05$ dan t hitung 3,026 < t tabel 1,703. Hal ini berarti hipotesis yang menyatakan budaya kerja berpengaruh signifikan terhadap kinerja karyawan Dinas Sosial Kabupaten Jember diterima. Budaya kerja merupakan suatu pola asumsi dasar bersama yang dipelajari kelompok tertentu untuk mengatasi masalah adaptasi eksternal dan integrasi internal Edgar H. Schein (2010). Hasil ini mendukung penelitian sebelumnya yang dilakukan oleh Shodiyah (2017) yang menyatakan disiplin kerja, motivasi berprestasi dan budaya kerja berpengaruh positif dan signifikan terhdap prestasi kerja guru SMKN 1 Jember.

\section{KESIMPULAN DAN SARAN}

Hasil pengujian penelitian variabel motivasi kerja, membuktikan bahwa motivasi kerja tidak berpengaruh signifikan terhadap kinerja karyawan. Hal ini dikarenakan motivasi kerja pada Dinas Sosial Kabupaten Jember sudah terbentuk, karena sebagian besar karyawan Dinas Sosial Kabupaten Jember sudah menjadi pegawai negeri sipil. Hasil pengujian penelitian variabel lingkungan kerja, membuktikan bahwa lingkungan kerja berpengaruh signifikan terhadap kinerja karyawan. Hal ini menunjukan bahwa lingkungan kerja yang baik dan nyaman, mampu membuat karyawan dapat meningkatkan kinerja karyawan di Dinas Sosial Kabupaten Jember. Hasil pengujian penelitian variabel budaya kerja, membuktikan bahwa budaya kerja berpengaruh signifikan terhadap kinerja karyawan. Hal ini menunjukan bahwa budaya kerja yang yang diterapkan di Dinas Sosial Kabupaten Jember mampu membuat karyawan meningkatkan kinerjanya.

Saran yang dapat diberikan oleh peneliti kepada Dinas Sosial Kabupaten Jember antara lain disarankan hendaknya instansi dapat meningkatkan kinerja karyawan lebih menitik beratkan pada motivasi kerja seperti memberikan perhatian pada setiap masalah secara detail didalam melakukan pekerjaan, akan menggambarkan ketelitian dan kecermatan dari karyawan didalam melaksanakan tugasnya. Dilihat dari hasil pengelolaan data yang didapat melalui kuesioner yang telah di isi oleh karyawan Dinas Sosial Kabupaten Jember tersebut diperoleh data bahwa motivasi kerja tidak berpengaruh dari pada lingkungan kerja dan budaya kerja. Sehingga dengan lebih memperhatikan motivasi kerja diharapkan dapat meningkatkan kinerja karyawan pada Dinas Sosial Kabupaten Jember.

Adapun yang harus diperhatikan oleh Dinas Sosial Kabupaten Jember terkait hasil penelitian adalah bahawa Dinas Sosial Kabupaten Jember diharapkan mampu memperbaiki dan mempertahankan gaya kepemimpinannya, karena gaya kepemimpinan akan berpengaruh penuh terhadap lingkungan kerja serta budaya kerja. Ada baiknya 
dimulai dari memotivasi atau bentuk kritikan yang membangun, supaya karyawan mampun berevaluasi agar lebih baik dalam kinerjanya. Hal ini juga untuk membangun kinerja karyawan Dinas Sosial Kabupaten Jember menjadi lebih baik.

Bagi peneliti selanjutnya disarankan untuk melakukan penelitian di luar variabel bebas yang digunakan dalam penelitian ini, misalnya budaya organisasi atau gaya kepemimpinan yang dapat digunakan untuk meningkatkan kinerja atau kepuasan kerja karyawan di Dinas Sosial Kabupaten Jember.

\section{DAFTAR PUSTAKA}

Alek, S. Nitisemito. 2008. Manajemen Personalia, Edisi kedua. Jakarta : Ghalia Indonesia.

Azhad, M. Naely, Anwar, Qomariah, Nurul. 2015. Manajemen Sumber Daya Manusia. Cahaya Ilmu Jember.

Antoni, Feri. 2008. Pengaruh Gaya Kepemimpinan Orientasi Tugas dan Orientasi Hubungan terhadap Motivasi Kerja dan Dampaknya pada prestasi Kerja Pegawai Pengadilan Tinggi Tata Usaha Negara Surabaya. Tesis. Universitas 17 Agustus, Surabaya.

Arikunto, S. 2008. Prosedur Penelitian Suatu Pendekatan Praktek. Edisi Revisi VI. Jakarta: Rineka Cipta.

Bangun, Wilson. 2012. Manajemen Sumber Daya Manusia. Jakarta : Erlangga.

Dessler Gary, 2009. Manajemen Sumber Daya Manusia. Jakarta : Edisi Kesepuluh Jilid Dua PT Indeks halaman 46.

Ferdinand, Augusty. 2008. Metode Penelitian Manajemen : Pedoman Penelitian untuk Penulisan Skripsi, Tesis, dan Disertasi Ilmu Manajemen, Badan Penerbit Universitas Diponegoro, Semarang.

Ghozali, Imam. 2009. Aplikasi Analisis Multivariate dengan Program SPSS. Semarang : UNDIP.

Gomes, Faustino cardoso. 2010. Manajemen Sumber Daya Manusia. Yogyakarta : Andi Offset

Handawiyah, Faridhotun. 2015. Pengaruh Kepemimpinan, Masa Kerja, dan Lingkungan Kerja terhadap Kinerja Karyawan PT. Glen Nevis Kalibaru, Banyuwangi. Skripsi Fakultas Ekonomi. Universirtas Muhammadiyah Jember.

Hanifah, Dwi. 2016. Analisis budaya kerja, motivasi kerja, dan lingkungan kerja terhadap keputusan kepuasan kerja karyawan. Fakultas Ekonomi Universitas Muhammadiyah Jember.

Hasibuan, Malayu S. P. 2010. Manajemen Sumber Daya Manusia. Jakarta: PT. Bumi Aksara 
Herzberg, Frederick. 2018. Herzberg's Motivation-Hygiene Theory and Job Satisfaction. Sunway Univesity Malaysia

Mangkunegara, Anwar Prabu. 2010. Manajemen Sumber Daya Manusia, Cetakan Kedua. Bandung, PT Remaja Rosdakarya.

Maulidia, Sefi. 2017. Pengaruh Kompensasi, Lingkungan Kerja, dan Gaya Kepemimpinan terhadap semangat pengajar pada SMKN 1 Jember. Fakultas Ekonomi. Universitas Muhammadiyah Jember.

Mulyadi. 2014. Audit 2, Edisi ke-6. Penerbit Salemba Empat, Jakarta.

Nawawi, Hadari. 2005. Manajemen Sumberdaya Manusia Untuk Bisnis Yang Kompetitif .Yogyakarta: Gajah Mada University Press.

Pattipawae, R. Dezonda. 2011. Penerapan Nilai Dasar Budaya Kerja dan Prinsip Organisasi Budaya Kerja Pemerinta Dengan Baik dan Benar. Jurnal Manajemen dan Organisasi Vol.17, No.3, juli-september, Hl.31-44.

Prasetyo, Andi. 2011. Analisis Kinerja Pemerintah Daerah Kabupaten Karanganyar dilihat dari Resiko Pendapatan Daerah APBD 2006-2008. Skripsi Surakarta. Universitas Muhammadiyah Surakarta.

Priyono, Bayu Hendro , Nurul Qomariah, Pawestri Winahyu.2018. Pengaruh Gaya Kepemimpinan, Motivasi Guru Dan Lingkungan Kerja Fisik Terhadap Kinerja Guru Sman 1 Tanggul Jember. Jurnal Manajemen Dan Bisnis Indonesia Vol. 4 No. 2 Desember, Hal. 144-160

Pusparani, Regina. 2013. Analisis pengaruh budaya kerja eksplisit dan implisit terhadap perilaku kerja dan kinerja karyawan. Fakultas ekonomi. Universitas negeri jember.

Robbins dan Judge. 2008. Perilaku Organisasi, Edisi Duabelas, Penerbit Salemba Empat: Jakarta.

Robbins SP, 2011, Prilaku Organisasi, Salemba Empat, Jakarta.

Sarwoto, 2008. Dasar-dasar Organisasi Manajemen. Jakarta : Ghalia Indonesia.

Schein, Edgar H. 2010. Organizational Culture and Leadership. Fourth Edition.JosseyBass. A Wiley Imprint, Market Street. San Fransisco CA.

Sedarmayati, 2008. Manajemen Sumber Daya Manusia, bandung : PT Refika Aditama.

2011. Manajemen Sumber Daya Manusia, reformasi birokrasi dan manajemen pegawai negeri sipil (cetakan ke lima) bandung : PT Refika Aditama.

Setyadi dan Waridin, 2008. Pengaruh Persepsi Karyawan Mengenai Perilaku Kepemimpinan, Kepuasan Kerja dan Motivasi Terhadap Kinerja. Jurnal Riset Bisnis Indonesia Vol.1 No.1, p. 63-74. 
Shodiyah, Ida Aminatus. 2017. Pengaruh Disiplin Kerja, Motivasi Berprestasi dan Budaya Kerja terhadap Prestasi Kerja pada Guru SMKN 1 Jember. Skripsi Fakultas Ekonomi. Universitas Muhammadiyah Jember.

Siagian, 2013, Manajemen Sumber daya Manusia, Bumi aksara, jakarta.

Sidanti, Heny. 2015. Pengaruh Lingkungan Kerja, Disiplin Kerja, dan Motivasi Kerja terhadap Kinerja Pegawai Negeri Sipil di Sekretariat DPRD Kabupaten Madiun. Jurnal JIBEKA Volume 9 nomer 1 februari 2015 : 44-53.

Sugiono,2013, Metode Penelitian Kualitatif Dan Kuantitatif, penerbit alfabeta, Bandung.

Sulton, M. 2017. Pengaruh Motivasi Kerja, Kepemimpinan, dan Budaya Organisasi terhadap Kepuasan Kerja Karyawan pada Dinas Sosial Kabupaten Jember. Skripsi Fakultas Ekonomi. Universitas Muhammadiyah Jember.

Sutrisno, Edy. 2010. Manajemen sumber daya manusia, Jakarta: Kencana Prenada Media Group.

Swasto, Bambang. 2011. Manajemen Sumber Daya Manusia. Malang, UB Press.

Umi Narimawati. 2008. Metodologi Penelitian Kualitatif dan Kuantitatif, Teori dan Aplikasi. Bandung: Agung Media.

Usman, Uzer Muhammad. 2008. Strategi Pembelajaran, Jakarta : Erlangga 